\title{
Assessment of knowledge of cancer and lymphoedema among breast cancer survivors
}

\author{
Aleksandra Krzywonos ${ }^{1}, K^{2} a t a r z y n a ~ O c h a ł e k^{1}$, Anna Krzywonos-Zawadzka², Kamil Pitala \\ 1Department of Rehabilitation in Traumatology, Clinical Rehabilitation University School of Physical Education, Cracow, Poland \\ ${ }^{2}$ Department of Clinical Chemistry, Medical University of Wroclaw, Wroclaw, Poland \\ ${ }^{3}$ Cracovian Center of Ortopedy and Rehabilitation, Cracow, Poland
}

\begin{abstract}
Aim: To evaluate the knowledge of breast cancer and lymphoedema symptoms among mastectomy survivors.

Material and methods: The research was carried out in the Centre of Oncology Branch in Cracow. The survey comprised 60 hospitalized patients as well as 30 healthy subjects from the Małopolska region. The scientific method used was a specially designed questionnaire.

Results: Women with a history of cancer demonstrate a health-oriented approach. The subjects known as the experimental group perform breast self-examinations, regularly visit a gynaecologist, are aware of the most severe mastectomy complication - lymphoedema, and recognize the impact of physical activity on it. Breast cancer operation survivors have a good knowledge of breast cancer and lymphoedema, however, existing shortcomings in practical issues are worrying. On the contrary, the control group neglects regular check-ups, evaluates its own knowledge as negligible and, most surprisingly, is not interested in the subject of breast cancer and lymphoedema, even though the subjects of the group believe that arm swelling is connected to all types of breast cancer surgeries.

Conclusions: Breast cancer survivors have a good knowledge of their disorder but are still lacking some essential information. Respondents from the control group have a limited knowledge in the field of cancer and lymphoedema, are not interested in breast cancer matters and are not encouraged by gynaecologists to perform breast self-examinations. Educational prevention programs should develop a health-oriented approach among all women and emphasize their basic role in therapy.
\end{abstract}

Key words: breast cancer, lymphoedema, knowledge, education, prevention.

\section{Introduction}

Nowadays, breast cancer is the most common cancer among Polish women. Breast cancer is the main cause of death among Poles between 40 and 55 years old. According to the Ministry of Health forecast, every fourteenth Pole will have breast cancer during her lifetime [1]. Standard treatments including surgery (axillary node dissection) and radiotherapy are consequently causing lymphatic system disorders [2-4]. Antineoplastic treatment is the main cause of lymphoedema that is not only associated with long-term physiotherapy, psychological damage, and deterioration of the quality of life, but also increases the risk of concomitant disorders (such as infections, inflammations or erysipelas) [5-11]. The statistics reflect the occurrence of lymphoedema associated with breast cancer surgery, reaching up to $50 \%$ of all cases (depending on the type of operation) [12]. According to the current knowledge, most of the breast cancer risk factors as well as the number of lym- phoedema-causing factors are modifiable [10, 13-18]. As reported by the European Code Against Cancer, even $80-90 \%$ of all types of cancer cases in Western populations can be assigned to environmental factors, such as eating habits and socio-cultural behaviours. Elimination or limitation of the exposure to risk factors should result in a reduced number of breast cancer incidences and subsequently, reduced number of lymphoedema incidences. These are all goals of early prevention, primary prophylaxis and educational programs that participants declare to be familiar with. The aim of this work was to evaluate the knowledge of breast cancer and following lymphoedema, among breast cancer survivors.

\section{Material and methods}

The survey was conducted among 90 women, taking as a criterion the minimum age of 25 years (suscep- 
tibility to breast cancer starts before the age of 24 years old) [19].

The subjects ( $n=90$ ) were divided into two groups: an experimental group of 60 women and a control group of 30 women with a non-random sampling method.

The experimental group (EG) was comprised of the consecutive patients from Małopolska treated for breast cancer at the Centre of Oncology Branch in Cracow and were one week after mastectomy surgery. The sample size was estimated on the grounds of the number of patients who underwent mastectomy in the Centre of Oncology Branch in Cracow during the previous year, taking under consideration the confidence level and the confidence interval. The control group (CG) included consecutive patients from gynaecological wards in Cracow (residents of Małopolska). To obtain basic data and trends regarding the pilot study, convenience sampling was used among consecutive patients who declared no cancer history.

The research method was the author's questionnaire designed on the basis of relevant literature. The survey consisted of 26 closed questions concerning breast cancer and lymphoedema. The interviewer administered the questionnaire to the participants and then, the $100 \%$ anonymous surveys were analyzed. The surveys were linked to the participants via an identification number. The author did not need to receive ethics approval for the study because of the nature of the method used. The time frame of participants' recruitment was 3 months.

All of the approached participants from the Centre of Oncology agreed to take part in the survey.

Statistical analysis was performed using Statistica v.8.0 (StatSoft, Cracow, Poland) and Microsoft Excel. The Pearson $\chi^{2}$ test was used for a multi-variant analysis. $P$ value of $<0.05$ was considered to be significant.

\section{Results}

The study group was diverse in terms of age, place of residence and education.

The average age of the women was 58.7 years old. The youngest respondent was 37 and the oldest one was 82 years old. The women in the control group were on average three years younger. The standard deviation (SD) of age in the study group was SD $=9.76$ and in the control group SD $=7.37$.

Most of the respondents (64.4\%) live in urban areas, the rest of the respondents (35.6\%) live in rural areas. Higher education was declared by $30 \%$ of the subjects, $32.2 \%$ had a vocational education: $27.8 \%$ - secondary education, $10 \%$ - primary education.

The analysis concerned the knowledge of breast cancer risk factors and lymphoedema. The results obtained in the experimental group were compared with the ones from the control group (Table I). The women were asked whether they had performed breast selfexamination at least once in their lives. In the EG, 81.7\% of the respondents reported that they performed the examination, while in the CG, up to $66.7 \%$ of the respondents never practiced it. Another question was related to gynaecologist check-ups. Sixty three point three percent (63.3\%) of respondents in the EG declared regular visits, while in the CG most women (56.7\%) visit their gynaecologists irregularly. A small number of women do not visit any gynaecologist.

Subsequently, the participants of the study were asked if the gynaecologist had ever asked them about breast self-examination and had showed them how to correctly perform it. The responses in both groups were similarly distributed - there were no statistically significant differences. Fifty-five percent (55\%) of the EG and $50 \%$ of the CG, respectively, have never been questioned by the doctor about breast self-examination and have not received any instructions. Only 20\% of the women in the EG and $6.7 \%$ in the CG were both requested and instructed. Knowledge of the most serious breast cancer surgical treatment complications turned out to be good in the EG - $60 \%$ of subjects indicated lymphoedema. On the contrary only $13.3 \%$ of the respondents in the CG indicated lymphoedema. The awareness of the lymphoedema treatment centres existence is significantly higher in the group of the operated women. Such centres are practically not known in the CG. Another question was aimed at assessing the subjects' knowledge concerning breast cancer and lymphoedema. Over forty-three percent (43.3\%) of the respondents in the EG claimed to have a good level of knowledge while $40 \%$ considered their knowledge as sufficient. The answers in the CG were different - none assessed their knowledge as very good or good, $46.7 \%$ considered it as sufficient, $16.7 \%$ as insufficient and $36.7 \%$ declared a negligible level of knowledge. Sixtyfive percent $(65 \%)$ of respondents in the EG admitted that the lack of physical activity after breast cancer surgery may be due to the lack of knowledge. On the contrary, in the CG, 63.3\% did not believe that lack of knowledge was the reason for the lack of activity in the group. The majority of respondents in both groups claimed that they have no knowledge concerning the impact of diet on lymphoedema treatment after breast cancer surgery.

Majority of subjects in both groups declared their knowledge of preventive actions (78.3\% in the EG and $56.7 \%$ in the CG). Additional sources of information about breast cancer and lymphoedema for the EG are health care professionals (35\%), medical sources (25\%), internet portals and medical services for "amazons" (30\%), and other media (10\%). Six percent (6\%) stated that they did not seek such information. The results in the CG show that $16.6 \%$ of respondents asked medical staff to get such information, 23\% derived their 
Tab. I. The survey questionnaire

\begin{tabular}{|c|c|c|c|c|c|c|}
\hline \multirow[t]{3}{*}{ Question } & \multirow[t]{3}{*}{ Answer } & \multicolumn{4}{|c|}{ Group } & \multirow{3}{*}{$\begin{array}{c}\chi^{2} \text { test } \\
\alpha<0.05^{\star}\end{array}$} \\
\hline & & \multicolumn{2}{|c|}{$\begin{array}{l}\text { Experimental } \\
\text { group }(\mathrm{EG})\end{array}$} & \multicolumn{2}{|c|}{$\begin{array}{l}\text { Control group } \\
\text { (CG) }\end{array}$} & \\
\hline & & $n$ & $\%$ & $n$ & $\%$ & \\
\hline \multirow{2}{*}{$\begin{array}{l}\text { Performing breast self-examination } \\
\text { at least once during the life time }\end{array}$} & Yes & 49 & $81.7 \%$ & 10 & $33.3 \%$ & \multirow{2}{*}{$\begin{aligned} \chi^{2} & =20.69 \\
p & <0.05\end{aligned}$} \\
\hline & No & 11 & $18.3 \%$ & 20 & $66.7 \%$ & \\
\hline \multirow[t]{3}{*}{ Gynaecologist check-ups } & Yes, regularly & 38 & $63.3 \%$ & 11 & $36.7 \%$ & \multirow{3}{*}{$\begin{array}{l}\chi^{2}=6.34 \\
p<0.05\end{array}$} \\
\hline & Yes, but irregularly & 21 & $35 \%$ & 17 & $56.7 \%$ & \\
\hline & No & 1 & $1.7 \%$ & 2 & $6.7 \%$ & \\
\hline \multirow{3}{*}{$\begin{array}{l}\text { Gynaecologist asking women if they } \\
\text { perform breast self-examinations or } \\
\text { giving instructions how to perform } \\
\text { the self-examination correctly }\end{array}$} & $\begin{array}{l}\text { Yes, the doctor asked and showed me } \\
\text { how to do it correctly }\end{array}$ & 12 & $20 \%$ & 2 & $6.7 \%$ & \multirow[t]{3}{*}{ NS } \\
\hline & $\begin{array}{l}\text { Yes, the doctor asked but he/she did } \\
\text { not show me how to do it correctly }\end{array}$ & 15 & $25 \%$ & 13 & $43.3 \%$ & \\
\hline & $\begin{array}{c}\text { No, the doctor did not ask and did not } \\
\text { show }\end{array}$ & 33 & $55 \%$ & 15 & $50 \%$ & \\
\hline \multirow[t]{4}{*}{ Attitude towards mammography } & $\begin{array}{l}\text { I feel uncomfortable, } \\
\text { but it is worth doing }\end{array}$ & 16 & $26.7 \%$ & 7 & $23.3 \%$ & \multirow[t]{4}{*}{ NS } \\
\hline & $\begin{array}{l}\text { I am doing mammography willingly } \\
\text { as taking care of my health }\end{array}$ & 33 & $55 \%$ & 19 & $63.3 \%$ & \\
\hline & Unconcerned & 10 & $16.7 \%$ & 4 & $13.3 \%$ & \\
\hline & I am too embarrassed to do it & 1 & $1.7 \%$ & 0 & $0 \%$ & \\
\hline \multirow{5}{*}{$\begin{array}{l}\text { The most severe complication after } \\
\text { breast cancer operation }\end{array}$} & Scar & 8 & $13.3 \%$ & 10 & $33.3 \%$ & \multirow{5}{*}{$\begin{array}{l}\chi^{2}=20.60 \\
p<0.05\end{array}$} \\
\hline & Lymphoedema & 36 & $60 \%$ & 4 & $13.3 \%$ & \\
\hline & Weakening of the body & 7 & $11.7 \%$ & 7 & $23.3 \%$ & \\
\hline & Psychological damage & 8 & $13.3 \%$ & 5 & $16.7 \%$ & \\
\hline & Pain & 1 & $1.7 \%$ & 4 & $13.3 \%$ & \\
\hline \multirow{4}{*}{$\begin{array}{l}\text { Knowledge about treatment centres } \\
\text { for breast cancer survivors }\end{array}$} & Don't know & 16 & $26.7 \%$ & 15 & $50 \%$ & \multirow{4}{*}{$\begin{aligned} \chi^{2} & =24.86 \\
p & <0.05\end{aligned}$} \\
\hline & There are no places like this & 6 & $10 \%$ & 12 & $40 \%$ & \\
\hline & $\begin{array}{l}\text { There are places like this, but I do not } \\
\text { know them }\end{array}$ & 16 & $26.7 \%$ & 2 & $6.7 \%$ & \\
\hline & There are places like this, I know them & 22 & $36.7 \%$ & 1 & $3.3 \%$ & \\
\hline \multirow{5}{*}{$\begin{array}{l}\text { Self-assessment of knowledge about } \\
\text { breast cancer and lymphoedema } \\
\text { (in } 1-5 \text { scale) }\end{array}$} & Very well & 5 & $8.3 \%$ & 0 & $0 \%$ & \multirow{5}{*}{$\begin{aligned} \chi^{2} & =38.96 \\
p & <0.05\end{aligned}$} \\
\hline & Well & 26 & $43.3 \%$ & 0 & $0 \%$ & \\
\hline & Enough & 24 & $40 \%$ & 14 & $46.7 \%$ & \\
\hline & Insufficiently & 5 & $8.3 \%$ & 5 & $16.7 \%$ & \\
\hline & Hardly know & 0 & $0 \%$ & 11 & $36.7 \%$ & \\
\hline \multirow{2}{*}{$\begin{array}{l}\text { Lack of knowledge can be the cause } \\
\text { of low physical activity in breast } \\
\text { cancer survivors }\end{array}$} & $\begin{array}{l}\text { Yes, if women knew that physical activ- } \\
\text { ity is important, they would exercise }\end{array}$ & 39 & $65 \%$ & 11 & $36.7 \%$ & \multirow[t]{2}{*}{$\begin{array}{l}\chi^{2}=6.50 \\
p<0.05\end{array}$} \\
\hline & $\begin{array}{l}\text { No, lack of knowledge is not the reason } \\
\text { for low physical activity }\end{array}$ & 21 & $35 \%$ & 19 & $63.3 \%$ & \\
\hline \multirow{3}{*}{$\begin{array}{l}\text { Impact of diet on lymphoedema } \\
\text { after breast cancer operation }\end{array}$} & Yes & 12 & $20 \%$ & 1 & $3.3 \%$ & \multirow{3}{*}{$\begin{aligned} \chi^{2} & =11.41 \\
p & <0.05\end{aligned}$} \\
\hline & No & 20 & $33.3 \%$ & 4 & $13.3 \%$ & \\
\hline & Don't know & 28 & $46.7 \%$ & 25 & $83.3 \%$ & \\
\hline
\end{tabular}


Tab. I. Cont.

\begin{tabular}{|c|c|c|c|c|c|c|}
\hline \multirow[t]{3}{*}{ Question } & \multirow[t]{3}{*}{ Answer } & \multicolumn{4}{|c|}{ Group } & \multirow{3}{*}{$\frac{\chi^{2} \text { test }}{\alpha<0.05^{*}}$} \\
\hline & & \multicolumn{2}{|c|}{$\begin{array}{l}\text { Experimental } \\
\text { group }(E G)\end{array}$} & \multicolumn{2}{|c|}{$\begin{array}{l}\text { Control group } \\
\text { (CG) }\end{array}$} & \\
\hline & & $n$ & $\%$ & $n$ & $\%$ & \\
\hline \multirow{2}{*}{$\begin{array}{l}\text { Knowing about preventative educa- } \\
\text { tional actions about breast cancer } \\
\text { (in the mass media/health } \\
\text { centres/from medical staff, etc.) }\end{array}$} & No & 13 & $21.7 \%$ & 13 & $43.3 \%$ & \multirow[t]{2}{*}{ NS } \\
\hline & Yes & 47 & $78.3 \%$ & 17 & $56.7 \%$ & \\
\hline \multirow{5}{*}{$\begin{array}{l}\text { Information source about breast } \\
\text { cancer and its complications }\end{array}$} & Health professionals & 21 & $35 \%$ & 5 & $16.7 \%$ & \multirow{5}{*}{$\begin{aligned} \chi^{2} & =33.68 \\
p & <0.05\end{aligned}$} \\
\hline & Specialized media - medical magazines & 15 & $25 \%$ & 0 & $0 \%$ & \\
\hline & $\begin{array}{l}\text { Internet - the Amazon web portals and } \\
\text { medical portals }\end{array}$ & 18 & $30 \%$ & 0 & $0 \%$ & \\
\hline & Non-specialized media & 6 & $10 \%$ & 7 & $23.3 \%$ & \\
\hline & Don't search for this kind of information & 10 & $6 \%$ & 19 & $63.3 \%$ & \\
\hline \multirow{3}{*}{$\begin{array}{l}\text { Importance of physical activity } \\
\text { as a prophylaxis and treatment } \\
\text { of lymphoedema }\end{array}$} & Yes & 57 & $95 \%$ & 5 & $16.7 \%$ & \multirow{3}{*}{$\begin{aligned} \chi^{2} & =57.58 \\
p & <0.05\end{aligned}$} \\
\hline & No & 0 & $0 \%$ & 5 & $16.7 \%$ & \\
\hline & Don't know & 3 & $5 \%$ & 20 & $66.7 \%$ & \\
\hline \multirow{4}{*}{$\begin{array}{l}\text { Overexertion has a negative influ- } \\
\text { ence on arm lymphoedema }\end{array}$} & No influence if performed rarely & 6 & $10 \%$ & 20 & $66.7 \%$ & \multirow{4}{*}{$\begin{aligned} \chi^{2} & =49.49 \\
p & <0.05\end{aligned}$} \\
\hline & No influence even if performed often & 1 & $1.7 \%$ & 2 & $6.7 \%$ & \\
\hline & No influence at all & 0 & $0 \%$ & 4 & $13.3 \%$ & \\
\hline & Yes, overexertion should be avoided & 53 & $88.3 \%$ & 4 & $13.3 \%$ & \\
\hline \multirow{4}{*}{$\begin{array}{l}\text { Special cosmetics for lymphoedema } \\
\text { affected arm may impact the size } \\
\text { and degree of the oedema }\end{array}$} & $\begin{array}{l}\text { No, there is no need to use some } \\
\text { special cosmetics }\end{array}$ & 33 & $55 \%$ & 22 & $73.3 \%$ & \multirow[t]{4}{*}{ NS } \\
\hline & Very little influence & 17 & $28.3 \%$ & 3 & $10 \%$ & \\
\hline & $\begin{array}{l}\text { Yes, significant/insignificant influence } \\
\text { if used for a short time only }\end{array}$ & 2 & $3.3 \%$ & 0 & $0 \%$ & \\
\hline & $\begin{array}{l}\text { Yes, significant impact, special cos- } \\
\text { metics should be always used }\end{array}$ & 8 & $13.3 \%$ & 5 & $16.7 \%$ & \\
\hline \multirow[t]{2}{*}{$\begin{array}{l}\text { Lymphoedema appears after every } \\
\text { breast cancer operation }\end{array}$} & $\begin{array}{l}\text { Yes, it is common after this type } \\
\text { of treatment }\end{array}$ & 9 & $15 \%$ & 19 & $63.3 \%$ & \multirow[t]{2}{*}{$\begin{aligned} \chi^{2} & =21.80 \\
p & <0.05\end{aligned}$} \\
\hline & $\begin{array}{l}\text { No, it does not appear always, } \\
\text { it depends on the type of operation }\end{array}$ & 51 & $85 \%$ & 11 & $36.7 \%$ & \\
\hline \multirow[t]{3}{*}{ Use of contraceptive pills } & Yes & 1 & $1.7 \%$ & 1 & $3.3 \%$ & \multirow[t]{3}{*}{ NS } \\
\hline & No, never used them & 45 & $75 \%$ & 22 & $73.3 \%$ & \\
\hline & No, but I used them some time ago & 14 & $23.3 \%$ & 7 & $23.3 \%$ & \\
\hline \multirow{3}{*}{$\begin{array}{l}\text { Contraceptive pills can be a risk fac- } \\
\text { tor for breast cancer }\end{array}$} & Yes & 23 & $38.3 \%$ & 6 & $20 \%$ & \multirow{3}{*}{$\begin{array}{l}\chi^{2}=9.90 \\
p<0.05\end{array}$} \\
\hline & No & 6 & $10 \%$ & 11 & $36.7 \%$ & \\
\hline & Don't know & 31 & $51.7 \%$ & 13 & $43.3 \%$ & \\
\hline \multirow{3}{*}{$\begin{array}{l}\text { Exposure to risk factors (radiation } \\
\text { exposure, ionizing radiation, high } \\
\text { magnetic field) during your current } \\
\text { or previous job }\end{array}$} & Yes & 2 & $3.3 \%$ & 1 & $3.3 \%$ & \multirow[t]{3}{*}{ NS } \\
\hline & No & 55 & $91.7 \%$ & 25 & $83.3 \%$ & \\
\hline & Don’t know & 3 & $5 \%$ & 4 & $13.3 \%$ & \\
\hline
\end{tabular}


knowledge from non-specialist sources of information and media, up to $63.3 \%$ did not seek any information concerning this topic.

Ninety-five percent (95\%) of the women in the EG confirmed the importance of physical activity in the treatment and prevention of lymphoedema, while 5\% had no knowledge concerning this topic. In the CG, only $16.7 \%$ confirmed the beneficial effects of exercise, as many women questioned the positive impact of activity but the majority of women $(66.7 \%)$ did not know whether the physical activity affected the swelling. At the same time, $66.6 \%$ of the CG believed that strain, if rare, does not affect lymphoedema. In contrast, $88.3 \%$ of EG said that overexertion should be avoided.

Different answers were obtained regarding the use of special cleaning agents and their impact on the quality and size of the swelling. Eighty-five percent (85\%) of the Oncology Centre patients acknowledged that swelling occurrence depends on the type of procedure in contrast with the CG, where $63.3 \%$ consider lymphoedema to occur irrespectively of the operation type.

Both groups have a similar distribution of responses concerning the contraceptive pills intake. However, the groups differ significantly in their opinions regarding the pills as a risk factor for breast cancer. Another question was related to exposure to risk factors such as ionizing radiation or high magnetic fields at work. In the EG, 3.3\% declared to be exposed to such stimuli, $91.7 \%$ of the women were not exposed, $5 \%$ did not know. In the CG also, 3.3\% were exposed, $83.3 \%$ were not exposed and $13.3 \%$ did not know if the work environment exposed them to this type of stimulus. In addition, in the EG, $73.3 \%$ of women confirmed suffering from lymphoedema. Over sixty-eight percent (68.3\%) of patients from the EG received education on and prevention of further treatment after the mastectomy surgery.

\section{Discussion}

An individual sense of responsibility for one's own health is a factor that determines regular medical appointments and examinations, monitoring alarming symptoms and participation in preventive actions. It is mainly the medical personnel who is responsible for the development of the health-oriented approach by educational activities in providing information to patients as well as in eliminating the prevailing false stereotypes about health and diseases. In the context of this study, one of the manifestations of pro-health approach is breast self-examinations, despite the fact that the benefits in reducing mortality are uncertain.

Regardless of the research centre, the results concerning breast self-examinations are similar - Paździor et al. demonstrates that $70 \%$ of the surveyed patients performed examinations [20], while Lewandowska et al. concludes that such examinations were declared by a total of $82 \%$ of the respondents - she indicates, however, that only $20 \%$ practice them regularly [21]. The author's own results are inconsistent. Nearly $67 \%$ of the women in the CG have never practiced breast self-examinations. The potential answer to why women do not check their breasts can be found by analyzing the results of the questions related to the visits to a gynaecologist. The women in both groups, although they are under the control of a gynaecologist - in the EG more regularly than in the CG - have never been asked by a gynaecologist about breast checking and have not been instructed how to properly perform the test $(50 \%$ and $55 \%$ in the EG and CG, respectively). In her study Cichońska et al. presents results showing that as many as $82 \%$ of the subjects during their visits to the gynaecologist have never had their breasts professionally examined [22]. It should also be noted that an important factor influencing the quality of breast examination is the phase of the menstrual cycle - a woman should control her breasts on the second or the third day of the menstrual cycle. In the cited study by Paździor et al., up to $42 \%$ of the women practicing the examination conduct it on any day of the cycle [20].

Przysada et al., in his study, emphasizes a broader knowledge of the research and the information related to the disease among the people with genetic predispositions to neoplasm [23]. Similarly, in the author's own study, women with a history of disease have a greater knowledge and awareness regarding examinations and possible complications. Sixty percent (60\%) correctly indicate lymphoedema as the most serious complication of the surgical breast cancer treatment. However, the women in the CG feared postoperative scars the most (34\%) and they indicated lymphoedema only in the last place on a par with pain (13\%).

Although the majority of mastectomy survivors perceive their knowledge in the field of breast cancer and lymphoedema as good, it is impossible not to notice that it is fragmentary. Nearly $60 \%$ had no idea of the treatment centres for women after cancer treatment, or they did not know where to find such places. What that means in practical terms is that most patients after mastectomy do not know where to look for help in the postoperative period.

What is more, patients in both groups were not able to assess the impact of diet on swelling.

Women in the CG assess their knowledge as sufficient, incomplete or negligible, while the latter two responses were given by the majority of the respondents. The question about the reasons for such a low cancer awareness among women from Małopolska appears in the last two questions. Firstly, it may be due to poor sources of information concerning breast cancer and its complications, indicated by the respondents in the CG. There is a low topicality and quality of information presented in the popular press and television. On the 
contrary, the EG receive the necessary information from the medical staff, look for it in medical magazines or on the internet on specific websites, including portals for "amazons" and they respond rather well. Cichońska et al. confirms that the expected source of information concerning cancer disease prevention is the medical staff, but also people with a history of disease. The best way of providing the information, according to the surveyed persons, is a direct interview [22]. Nevertheless, as it was stated in the Florek-tuszczki's study, only $25 \%$ of women receive information on cancer from gynaecologists while TV is the source for $60 \%$ of the respondents [23].

According to the study of Przysada et al., doctors are a source of information only for $4 \%$ of the respondents. What is more, $60 \%$ of women during their medical visits sporadically have their breast controlled and over one third of women have never been advised to perform ultrasound or mammography [24]. It is obvious to point to the fact that gynaecologists still insufficiently participate in health promotion and disregard the subject of both cancer and lymphoedema, despite the strong emphasis on the importance of the educational activities in "Recommendations on the prevention and early diagnosis of changes in the mammary gland" issued by the Board of the Polish Gynaecological Society [25]. The importance of dialogue between the medical staff and patients is also emphasized by Ridner in his comprehensive study on the impact of education on lymphoedema among breast cancer women [4]. Nevertheless, medical professionals' educational task is not as easy as it may be thought while there is not much interest among healthy Poles in the most killing cancer [1]. This issue is also highlighted by Cichońska et al. who claims that some women deliberately postpone examination, some of them are not interested in it, and some underestimate the problem and believe that they are not affected [22]. The described approach is similar among the women in our study who admitted that they do not seek cancer-related information, they are also not aware if during their work they are exposed to risk factors. However, these are attitudes that cannot be accepted, firstly for health reasons and secondly from an economic point of view. Women need to understand that the process of therapy depends mainly on their attitude and on observing their own body, controlling distressing symptoms and compliance with the examination calendar. It is essential to remember that to achieve a therapeutic success there is not only a need for well-prepared and professional medical staff but as also for an aware, involved and participating patient.

Taking into consideration that knowledge of the risk factors and implementation of preventative behaviour can minimize the risk of cancer and consequently the risk of lymphoedema, educational programs to prevent cancers have been designed. The question is if they could expand women's knowledge, bring some essential facts and prompt women to change their lifestyles. The survey shows that healthy women from Małopolska are not interested enough in expanding their knowledge in this field. That forces us to think about the changes that need to be done to improve awareness of women, modifications that will fill in huge information gaps. The author's findings suggest that such a program can be designed to overcome the knowledge gaps.

In the future, possible confounding factors such as medical education and cancer history in the family of participants should be taken into account to improve the survey. Results will be more valuable if the survey group is enlarged in the future.

\section{Disclosure}

Authors report no conflict of interest.

\section{References}

1. Didkowska J, Wojciechowska U, Zatoński W. Nowotwory złośliwe w Polsce w 2009 roku. Instytut - Centrum Onkologii, Warszawa 2011.

2. Kaufmann M, Marrow M, von Minckwitz G, et al. Locoregional treatment of primary breast cancer. consensus recommendations from an international Expert Panel. Cancer 2010; 116: 1184-1191.

3. Szuba A, Rockson G. Lymphedema: classification, diagnosis and therapy. Vascular Medicine 1998; 3: 145-156.

4. Ridner SH. Pretreatment lymphedema education and identified educational resources in breast cancer patients. Patients Education and Counseling 2006; 61: 72-29.

5. Norman SA, Russel A, Potashnik S. Lymphedema in breast cancer survivors: incidence, degree, time course, treatment, and symptoms. J Clin Oncol 2009; 27: 390-397.

6. Robinovitz B. Psychosocial issues in breast cancer. Obstet Gynecol Clin North Am 2002; 29: 233-247.

7. Schmitz KH, Troxel AB, Cheville A, et al. Physical Activity and Lymphoedema (The PAL Trial): assessing the safety of progressive strength training in breast cancer survivors. Contemp Clin Trials 2009; 30: 233-245.

8. Pinto AC, Azambuja E. Improving quality of life after breast cancer: Dealing with symptoms. Maturitas 2011; 70: 343-348.

9. Fu MR, Ridner SH. Post-breast cancer lymphedema: part 1. Am J Nurs 2009; 109: 48-54.

10. Fu MR, Ridner SH. Post-breast cancer lymphedema: part 2. Am J Nurs 2009; 109: 34-41.

11. Ochałek K. Prevention of lymphoedema. Contemp Oncol (Pozn) 2011; 15: 354-356.

12. Łobaziewicz W, Kołodziejski L. Chirurgia sutka. Leczenie i rehabilitacja chorych na raka sutka. Medycyna Praktyczna - Chirurgia 2012; 3: 30-41.

13. Doś J, Gutowski P, Górska-Doś M. Występowanie oraz czynniki ryzyka obrzęku limfatycznego u kobiet po operacji raka piersi. Ann Acad Med Stetin 2009; 55: 30-34.

14. Dziura I, Grądalski T. Wiedza o czynnikach wyzwalających powstanie obrzęku chłonnego i stosowanie się do zaleceń profilaktycznych u chorych po mastektomii. Rehabilitacja Medyczna 2008; 12: 14-18.

15. Tirona MT, Sehgal R, Ballester O. Prevention of breast cancer (part I): epidemiology, risk factors, and risk assessment tools. Cancer Invest 2010; 28: 743-750.

16. Tirona MT, Sehgal R, Ballester O. Prevention of breast cancer (part II): risk reduction strategies. Cancer Invest 2010; 28: 1070-1077.

17. National Lymphedema Network, Medical Advisory Committee. Lymphedema Risk Reduction Practices. 2011.

18. Hayes S, Janda M, Cornish B, et al. Lymphedema after breast cancer: incidence, risk factors and effect on upper body function. J Clin Oncol 2008; 26: 3536-3542. 
19. Europejski kodeks walki z rakiem. Centrum Onkologii - Instytut im. Marii Skłodowskiej-Curie, Warszawa 2009; 17-18.

20. Paździor A, Stachowska M, Zielińska A. Wiedza kobiet na temat profilaktyki raka piersi. Nowiny Lekarskie 2011; 80: 419-422.

21. Lewandowska A, Mess E, Kruk W. Women's knowledge on uterine cer vix cancer and breast cancer prevention. Onkol Pol 2012; 15: 5-8.

22. Cichońska M, Borek M, Krawczyk W, et al. Wiedza kobiet w zakresie zapobiegania nowotworom piersi i raka szyjki macicy. Acta Scientifica Akademiae Ostoviensis 2012; 1: 5-26.
23. Florek-Łuszczki M. Poziom wiedzy mieszkanek wsi na temat czynników ryzyka zachorowania na nowotwór piersi oraz zasad profilaktyki. Medycyna Ogólna 2010; 16: 406-415.

24. Przysada G, Bojczuk T, Kuźniar A, et al. Poziom wiedzy na temat profilaktyki i wczesnego rozpoznania raka piersi. Young Sports Science of Ukraine 2009; 5: 129-136.

25. Spaczyński M. Rekomendacje Zarządu Głównego PTG w sprawie profilaktyki i wczesnej diagnostyki zmian w gruczole sutkowym. Ginekologia po Dyplomie 2005; 4: 92-93. 